\title{
CONTRAPESO. LA VIDEO DANZA, O LA COREOGRAFÍA DE LA MIRADA
}

\author{
COUNTERWEIGHT. THE \\ VIDEO DANCE OR THE \\ CHOREOGRAPHY OF WATCHING
}

Por:

Alejandra Toro

Profesora Escuela de Comunicación Social

Universidad del Valle

atocade@gmail.com

Resumen: Este artículo propone una exploración de la video danza a través de la mirada de dos de sus mayores exponentes: el realizador audiovisual Douglas Rosenberg y el coreógrafo Merce Cunningham. En este cruce de caminos, examinaremos el valor de la video danza como obra significante y metafórica de la unión de las nuevas tecnologías y la danza, y como representación simbiótica del Cuerpo y la Imagen en movimiento. La video danza es una práctica artística aún desconocida y desdeñada pero cuyas posibilidades creativas son insospechadas. Proponiendo una narrativa propia a partir de las experiencias de la danza y el video, la video danza interpela al espectador como parte fundamental de la construcción de su discurso.

Palabras clave: Cuerpo, danza, video, video danza, medio digital, nuevas tecnologías, reproducción, montaje, obra de arte, pantalla, interpretación, espectador.

Abstract: This article seeks for the examination of video dance thru the statements of two of its major's references: the filmmaker Douglas Rosenberg and the choreographer Merce Cunningham. By crossing their points of view, we will review video dance's value as a signifier and metaphorical work of the union of contemporary technology and dance. We will underline video dance as a symbiotic representation of body and moving images. Yet unknown and disdained, video dance is an artistic practice with unsuspected creative possibilities. By creating based on dance and video experiences narratives of its own, video dance addresses the viewer as a fundamental part of the construction of its speech.

Key words: Body, dance, video, video dance, digital media, contemporary technology, reproduction, editing, work of art, screen, performance, viewer. 


\title{
CONTRAPESO
}

\section{La video danza, o la coreografía de la mirada}

\author{
La pantalla como espacio coreográfico es un lugar de exploración de la \\ danza como sujeto, objeto y metáfora. Un lugar de encuentro para ideas de \\ tiempo, espacio y movimiento. Ni la danza ni los medios para manifestar \\ (la coreografía) están al servicio uno de otro, sino que son compañeros o \\ colaboradores en la creación de una forma híbrida. \\ Douglas Rosenberg ${ }^{1}$
}

Esta cita de Douglas Rosenberg es muy sugestiva. ¿La pantalla, un espacio coreográfico? ¿Un lugar de exploración de la danza? ¿De encuentros del espacio, el tiempo y el movimiento? ¿Y de qué forma híbrida estamos hablando? Un fragmento de la cita ha sido retirado, y voluntariamente se restituye ahora: la video danza es la construcción de una coreografía que sólo vive cuando está encarnada en un video, filme o en tecnologías digitales. La referencia de Douglas Rosenberg a la video danza es como un canto de sirenas. Pero al contrario de Ulises, es bueno dejarse seducir por el espejismo. Comunicación social y danza: un canto de sirenas lleno de posibilidades...

Pero ya puntualmente, ¿qué es la video danza? Incomprendida, desdeñada por directores de cine, coreógrafos y bailarines, en búsqueda de legitimidad, casi que marginal, la video danza ha recorrido un tortuoso camino en busca de su identidad. Los académicos han fallado en definir sus límites y establecer sus campos de acción. Hoy por hoy, sigue siendo borroso el concepto de video danza y las referencias sobre el tema no abundan.

La primera interrogación es ortográfica. ¿Cómo se escribe “video danza”? ¿En dos palabras, video danza? ¿En dos palabras separadas por un guión, video-danza? ¿O videodanza, en un solo vocablo? Los diferentes autores que tratan el tema parecen no estar de acuerdo en su ortografía.

El género de la palabra también suscita preguntas: ¿el video danza o la video danza? ¿Femenino o masculino? Ambas posibilidades están presentes en la literatura consultada.

Más que una situación anecdótica, lo que se intenta subrayar aquí es que, aun hoy, alrededor de 40 años después de las primeras experimentaciones entre danza y cine, parece permanecer el conflicto entre la primacía de un arte sobre otro. Porque lo que se observa en cuanto a la video danza refiere, es que ésa ha sido la constante histórica entre ambos productos. La relación entre el video y la danza ha sido tensionada por marcas de poder entre Cuerpo e Imagen, por una relación de subordinación donde una práctica artística se encontraba al servicio de la otra. 
Así, ha existido la tendencia a desprestigiar la video danza, asociándola tanto a un subproducto de la danza como a un subgénero de lo audiovisual. Para muchos coreógrafos, hacer danza para la cámara era una tarea infinitamente ingrata. La mecánica de la cámara, el mundo del estudio y de la edición eran tan extraños e intimidantes que los resultados obtenidos implicaban grandes sacrificios artísticos. La danza entraba en el mundo de la pantalla y los coreógrafos y bailarines sentían que su trabajo era manipulado y utilizado como herramienta para apoyar otros lenguajes ajenos. Utilizado como mero registro del movimiento, el video tenía como objeto asegurar la reproducción de la coreografía, con un resultado frustrante para el bailarín y el coreógrafo. El registro, plano, no captaba ni la totalidad ni la complejidad de la obra o del movimiento. De la misma manera, los realizadores cinematográficos sentían la misma frustración al limitarse a grabar una coreografía. No era un gran reconocimiento para los cineastas firmar tales productos audiovisuales.

Pero con el diálogo acrecentado entre ambas disciplinas, se percibió que la danza podía ser vista de otra manera a través de la cámara y que ésta podía aportar otros medios para comunicarse, con nuevos contenidos, nuevas narrativas y una poética propia. El cortejo ha sido mutuo y los resultados, más que seductores.

¿Qué es pues la video danza? ¿Video? ¿Danza? ¿O es, como se ha llegado a definir, un producto híbrido entre los dos?

Podrían darse para empezar algunas definiciones básicas: la video danza es la integración de dos lenguajes, el video y la danza. Se graba por lo general en espacios no convencionales, diferentes del teatro: pienso en bibliotecas, restaurantes, cafés o bares, en una plataforma en medio del mar o en un cultivo de girasoles gigantes. La imagen se manipula, como en toda producción cinematográfica, en el momento de la edición. A diferencia de la danza, que es efímera e irrepetible, la video danza es un producto no perecedero y que trasciende las culturas. Por último, el producto final es audiovisual. Entendemos pues por video danza aquellas piezas en las que se desarrollan formas específicas de coreografías para el espacio de la cámara o campo de vista del monitor.

Bien. Pero para que esta plana pero necesaria descripción introductoria tenga una pincelada de poesía, conviene retomar la terminología que emplea Rodrigo Alonso. Este especialista en arte contemporáneo y nuevos medios llama a la video danza, "la coreografía de la mirada" ${ }^{2}$. A lo largo de este artículo, se intentará demostrar por qué se asume en él esta denominación.

\section{Híbrido}

La video danza, como el video arte de la cual es heredera, es una disciplina artística relativamente reciente: comenzó en Estados Unidos y Europa a mediados del siglo XX. La propia consideración del video como imagen en movimiento encaja perfectamente con el concepto de danza. La comunión de ambas disciplinas arroja una obra con un resultado simbiótico entre el contenido (en este caso la coreografía) y el medio. Es decir, que uno no existe sin el otro, y el significado y fin de la obra se pierden si no están ambos elementos unidos. La cita inicial de Douglas Rosenberg, uno de los mayores exponentes de la video danza desde su creación, toma aquí toda su relevancia: "La video danza es la construcción de una coreografía que sólo vive cuando está encarnada en un video, film o tecnologías digitales". ${ }^{3}$

Se trata pues por un lado de crear un documento audiovisual de gran calidad artística y experimental, dando valor a cualidades como la originalidad, la belleza, la estética o la realización, la fluidez cinematográfica y técnica. De experimentar con ángulos, composición, iluminaciones, locaciones y técnicas de post-producción. Pero por otro lado, 
también se busca potenciar el valor de la danza como forma de expresión artística: mostrarla como manifestación estética y poética y tener la posibilidad de capturar su arte, fuerza y belleza a través de clips audiovisuales. Aliada con el video, la danza adquiere una doble potencialidad: la inherente a la propia naturaleza del movimiento y la creatividad añadida propiciada por el empleo del video.

Como forma híbrida, han surgido proyectos entre creadores cuyas sendas nunca se hubieran cruzado, y que hoy habitan un espacio común y sientan las bases de un diálogo en continuidad. Calificada como "video en movimiento", territorio creativo entre el Cuerpo y la Imagen, la video danza propone una narrativa diferente, una estructura innovadora, unos recursos que enriquecen los procesos creativos y, sobre todo, propician el diálogo y la cocreación entre estas dos disciplinas cuya mezcla puede resultar maravillosa.

\section{Contrapeso}

El título de la obra aparece, borroso, en la pantalla negra. Las letras se van uniendo unas a otras, para difuminarse luego. CONTAR PESO, se lee primero. Pero no, no se trata de contar peso. CONTRA PESO, de eso se trata.

Estamos hablando de la obra de video danza "Contrapeso" o "Counterweight" de Cassio Carvalho, músico, compositor y realizador brasilero. La coreografía e interpretación son de Agustina Albaressi y Eva Harvez y la fotografía de Christian Vega. Fue realizada en Buenos Aires en el 2011.

Dos bailarinas acostadas en un piso de madera. Un fondo oscuro, un video en blanco y negro, casi en sepia. Una iluminación cefálica, tenue. Empieza la danza. Sin música. Desde el inicio, el realizador nos cuenta una historia, la de la chica del pelo corto. Poniendo la cámara desde la mirada de ella, percibimos sus miedos y sus angustias.

La mano de la bailarina se desliza por la cara de su compañera. Cuando los dedos se resisten al contacto, parece que la carne se estirara. Un ligero ralentí y un sonido como de "chicle", incorporado en el instante preciso, provocan esta extraña sensación.

Hay tensión entre las bailarinas, es un combate, es el poder quien se juega su lugar. Un plano desde arriba. Se cierra, como la mirilla de una puerta. Pesada, como la puerta de una cárcel. Sensualidad y desamor en constante contrapeso. Hacia afuera, hacia adentro, se sueltan, se agarran de nuevo. Fuerzas centrifugas y centrípetas, contrapeso con las manos, la cadera en el hombro, el cuello en la espalda. Depositan todo su ser sobre la otra, toda su confianza en el otro cuerpo. Es la fuerza de la otra la que te sostiene, es tu aliada, tu seguridad, tu supervivencia.

Pero la chica del pelo corto tiene monstruos que la habitan. Oímos sus voces y sus vértigos. Tiene miedo de caer, de caer mal, de que su compañera no aguante su peso. $\mathrm{O}$ de que la deje tirada, voluntariamente. 
Se filtra otra historia, más sórdida, incomprensible, inesperada. Es nuevamente la chica del pelo corto quien, después de un giro sobre el parquet... ¿sueña? ¿imagina? ¿recuerda? La visión de una habitación se intercala, solo dos segundos, como una alucinación, casi subliminal. Unas estanterías, iluminadas con unas lucecitas de Navidad. Ella se recuesta a la puerta, huyendo de algo, de alguien. Bloquea la puerta con su cuerpo. Extraña y hermosa imagen de otros mundos, de otros sueños, que no podemos más que imaginar...

Se corta la imagen en dos a nivel de la cintura: dos pantallas se superponen horizontalmente, cuatro bailarinas danzan en contrapunto. Nos recuerdan que hay una cámara y un proceso de edición. La otra bailarina se levanta con la ayuda de los brazos en un movimiento amplio y hacia afuera. Con la ayuda del montaje, repite el movimiento varias veces, imposible gesto en la danza. Parece un molino de viento.

Se amplifican los ruidos, como si fueran de tira cómica: la respiración se escucha profunda, pesada; se percibe cada sonido de la mano que roza la tela, cada contacto de un cuerpo con el otro; un eco metálico se produce cuando las dos bailarinas cierran sus manos sobre la pierna de la otra: se escucha el "crujido" del hueso al partirse. Cuando cae el cuerpo pareciera como si llevara dentro millones de piedras.

En cuanto a la mirada, el espectador es una especie de "observador omnisciente": con la superposición de planos lo ve todo, ve los movimientos desde arriba, desde los lados, desde afuera. Rostros de cerca, desenfocados, primeros planos, ve lo que ve la bailarina: vemos, borrosa, la visión que tiene al situarse debajo de su compañera.

Una moneda cae. Retumba largo. No se ve. No es necesario. Aunque no la veamos, la vemos rodar sobre sí en un giro acelerado.

Cuando cesa el ruido de la moneda, una respiración, jadeante, agitada. ¿La de las bailarinas? No, apenas si mueven el tórax. Es la respiración del narrador. Agotado, exaltado, nervioso, mudo. Es la nuestra.

La música, al fin, y unas pocas notas tristes acompañan el fade out progresivo hacia el final.

Un contrapeso de pesos, claro, pesos humanos, carne, huesos y piel, pero quizás también un contrapeso de vidas e historias. Un contrapeso de danza, técnica y poesía. Un "contar peso" que ha durado 4 minutos y 9 segundos. Un maravilloso ejemplo de la unión del video con la danza.

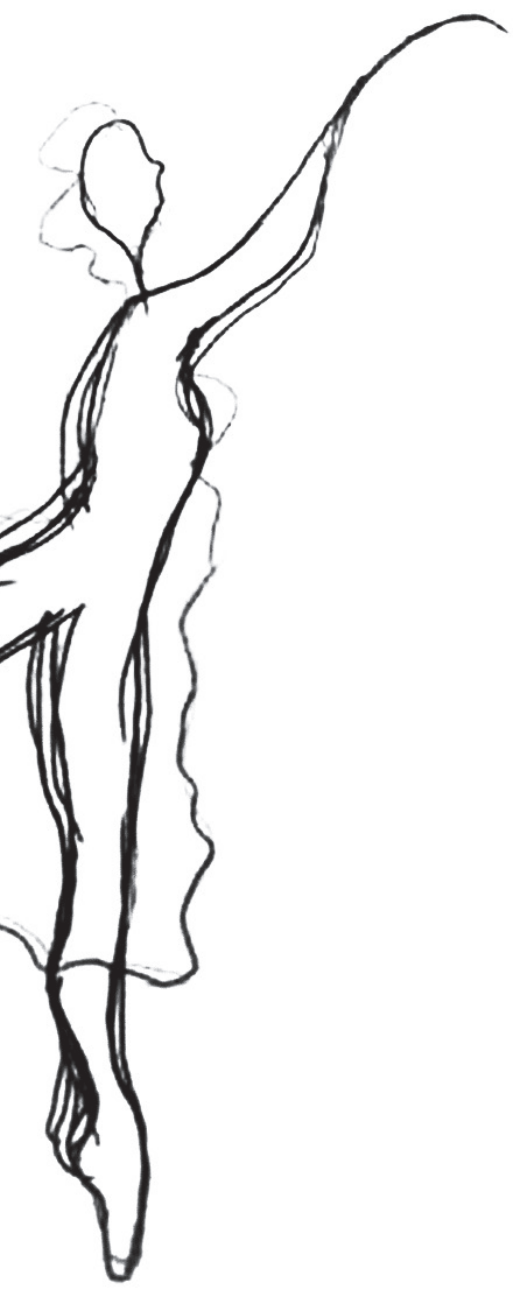




\section{Tiempo y espacio}

El análisis de "Contrapeso" nos permite adelantar desde ya ciertas conclusiones. Abrimos la discusión con la expresión "la coreografía de la mirada" de Rodrigo Alonso. Pues bien, lo que marca la diferencia del video con la danza en vivo es la manera como la cámara orienta al espectador. Si toma un movimiento humano y lo desestructura, en el momento de volverlo a ensamblar en la edición, lo que emerge es completamente diferente. Es más que la suma de las partes.

Gracias a la video danza entramos en dimensiones antes no concebidas. Se pueden trabajar conceptos y acciones de la danza de manera atemporal y superar límites espaciales: un salto puede congelarse y repetirse al infinito o un grito volverse mudo. Los recursos del medio se emplean, además, para llevar a cabo movimientos, extensiones corporales y formas físicamente imposibles de lograr. Las imágenes pueden crear un espacio/tiempo condensado en un cuadro al excluir movimientos secundarios a través del montaje o hacer un empalme imposible en la realidad entre dos movimientos.

El tiempo del video no es el mismo de la danza. El video permite reunir acciones coreográficas registradas en diferentes momentos, eliminar los nexos que llevan de una postura a la otra y por efectos de la edición, repetir movimientos de forma cíclica, o al
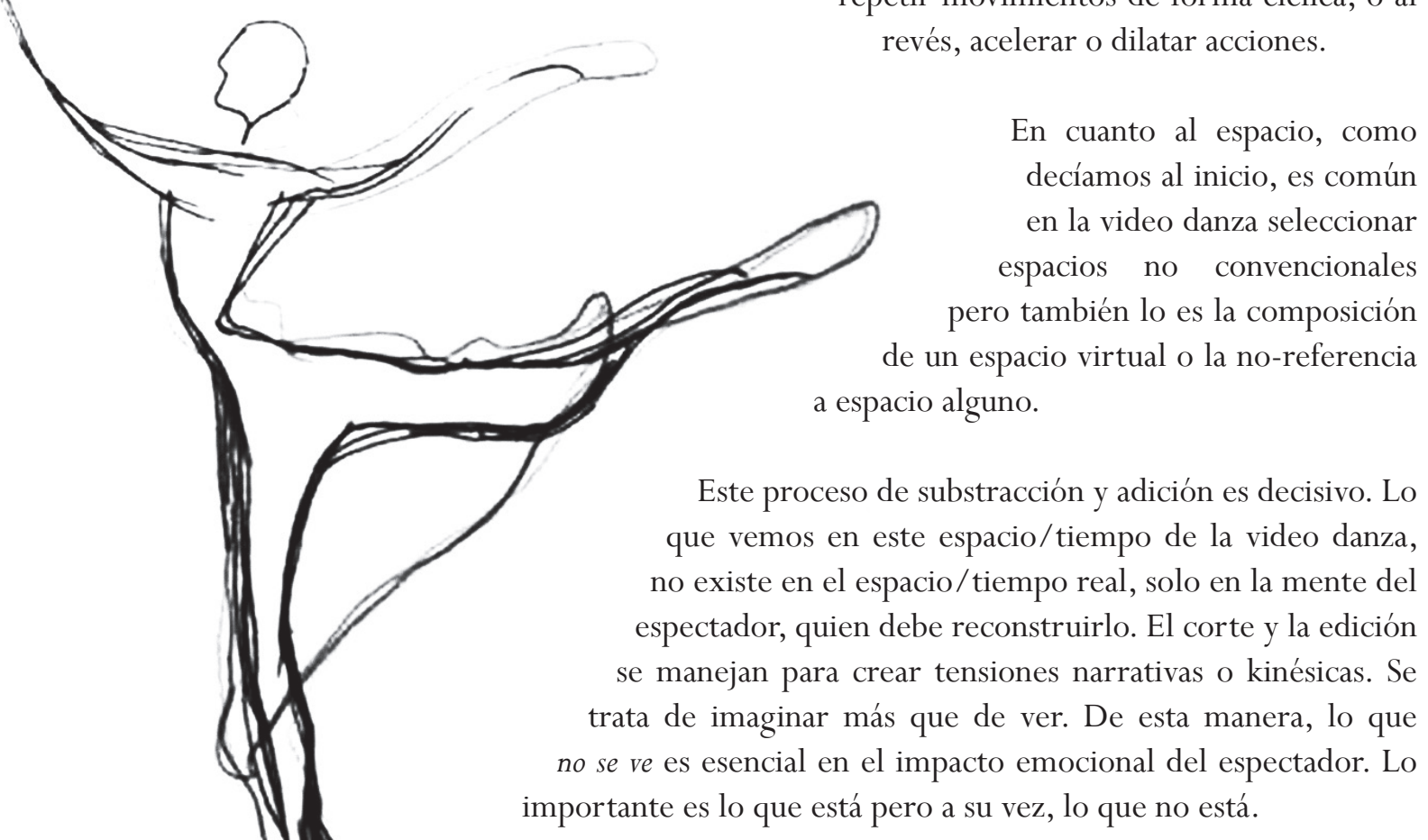
La coreografía debe ser muy bien conocida por el realizador. Su trabajo, al crear danza para la cámara, empieza extrayendo las posibilidades visuales del movimiento. La mirada del director analiza, diseca, revela y re ensambla la coreografía. El coreógrafo no controla el movimiento de la cámara. Es en esta negociación entre el ojo del coreógrafo y el del realizador audiovisual que emerge la relación simbiótica entre Cuerpo e Imagen. Es en este espacio donde surge la video danza. "La video-danza es un género en el que el coreógrafo lo tiene que ser tanto a nivel físico como visual”, dice Rebeca Carrillo ${ }^{5}$. El coreógrafo y el realizador pueden ser el mismo, pero deben ser dos sus miradas al hacer video danza.

El lenguaje del cine nos permite participar de una obra desde múltiples puntos de vista, nos permite una definición del tiempo y del espacio constantemente cambiante y fluida. La bailarina de danza oriental Elena García así lo expresa:

\begin{abstract}
La riqueza creativa que provee este género con respecto a la representación escénica convencional dada por el escenario a la italiana es entonces fascinante, ya que permite la posibilidad de adoptar cualquier ángulo, cualquier tiempo (no es realista y se pueden cambiar las velocidades); cambiar el espacio, variar la distancia entre el espectador y el intérprete y obtener planos detalle, fundir una imagen, asociar de manera distinta, incluir las asociaciones del bailarín, su pensamiento. En síntesis, "construir un relato de manera distinta, generalmente no lineal” (...). La propia naturaleza de la cámara, con su capacidad de acercarse y alejarse, y de enfocar claramente un área muy pequeña, invita a la investigación del movimiento y su desarrollo a un nivel muy íntimo ${ }^{6}$.
\end{abstract}

El cine, finalmente, puede focalizarse en un detalle, fracturar el cuerpo, moverse con o en contra del cuerpo del bailarín, llevando al espectador con él. Esta intimidad se genera en la relación entre el camarógrafo y el bailarín o bailarina.Y a través de ella, se percibe la fragilidad del bailarín, su mundo interior, su vulnerabilidad. Como dice Rodrigo Alonso:

El ojo de la cámara permite rescatar zonas, sectores que muchas veces son corporales y que otorgan una dimensión inusual al cuerpo como lugar a recorrer y/o habitar. Toda una estética del cuerpo como terreno a explorar subyace en los primeros planos o los detalles que el cuadro de la cámara recoge y la pantalla coloca a nuestra consideración ${ }^{7}$.

"Un gesto pequeño e insignificante en el escenario puede transformarse, cuando se ve a través de la lente, en poético y grandioso, mientras la respiración o los pasos del bailarín pueden convertirse en puntos focales de la obra", afirmaba Douglas Rosenberg8. Pareciera como si esta frase hubiera sido enunciada para describir "Contrapeso" de Carvalho... Esa cercanía, esa vulnerabilidad evidente de los bailarines que ha captado la cámara es lo que conmueve al espectador. Es lo que lo conecta a la obra, es lo que lo hace olvidar la técnica para quedarnos solo con la poesía. Es aquello que se llama la coreografía de la mirada... 
Por otro lado, es importante también anotar que si bien el cine se ha visto influenciado por la danza, la inversa también es válida. La danza como puesta en escena teatral, se ha visto modificada por las técnicas de la televisión y del video, no solo en su estructura sino también en la integración de las nuevas tecnologías en el guión. Con la video danza, el video deja de ser un instrumento de registro documental, y pasa a ser elemento integrante del espectáculo. La tecnología se vuelve personaje e interactúa con los mismos bailarines, imponiendo su lógica. De acuerdo con Valeria Cotaimich, dos aspectos fundamentales caracterizan la práctica escénica: la materialidad del cuerpo en escena y el modo de configuración discursiva y textual que se pone en juego (lo que se conoce como dramaturgia teatral) ${ }^{9}$. Valeria Cotaimich, docente e investigadora en Artes y Ciencias Sociales de la Universidad Nacional de Córdoba, Argentina, analiza la teatralidad emergente en puestas en escena que incluyen la utilización de nuevas tecnologías. Estas transformaciones serían el resultado de la libertad que hoy existe al hacer confluir el texto escrito, la actuación, el sonido, la iluminación, -componentes tradicionales de la puesta en escena-, con nuevos elementos pertenecientes al dominio de la ciencia y la tecnología.

La integración en el teatro y la danza de nuevas estéticas mediáticas, donde confluyen medios y soportes tecnológicos (televisión, fotografía, cine, imagen y sonido digital) implican un reposicionamiento del sujeto, dice Cotaimich, en lo que respecta a sus modos de percibir. Estas transformaciones tecnológicas, o lo que ella llama "nuevos modos de concebir el cuerpo en la configuración escénica”, suponen un papel más activo del espectador, que excede los límites de la recepción. Estas transformaciones, concluye la argentina, dan cuenta de nuevas narrativas que cambian el modo en que el espectador percibe, concibe y hace el mundo a partir de la palabra y la imagen.

En otras palabras, asistimos a una reproducción corpórea, en términos de Rosenberg, de una actuación tecnológicamente mediada. Merce Cunningham fue uno de aquellos coreógrafos que incluyó pantallas gigantes en sus actuaciones en escena, haciendo que tanto sus bailarines como los espectadores interactuasen (y bailasen) con la tecnología.

\section{Merce Cunningham o el cuerpo que baila}

Si la video danza empezó a tener un mayor reconocimiento es en particular gracias a la utilización del video por grandes figuras de la danza. Así, Merce Cunningham es una referencia obligatoria en el campo de la video danza. Su propuesta artística, centrada en una exploración de nuevas maneras de concebir el espacio y el tiempo en la danza, ya prefiguraba una propuesta a contracorriente de lo existente.

Fallecido en julio del 2009, Merce Cunningham, gran figura de la danza norteamericana, ex alumno de Martha Graham, seguía bailando a la edad de 90 años y creaba sus propias obras. Es considerado como el bailarín y coreógrafo que realizó la transición conceptual entre danza moderna y danza contemporánea, en particular al desolidarizar la música de la coreografía y al dejar que, como él mismo decía, "el azar irrumpiera en su obra”. Lo aleatorio era pues, vital en la creación de Cunningham. 
Todos los artistas que gravitaban alrededor suyo, especialmente quien fuera su compañero hasta su muerte en 1992, el compositor musical John Cage, eran hombres y mujeres profundamente abiertos al diálogo con la sociedad de su tiempo. Artistas urbanos que acogieron en sus obras manifestaciones artísticas sonoras y visuales, como los avances tecnológicos de su época. Así, en las coreografías de Cunningham cohabitan la danza, la música y las artes plásticas. Trabajada cada una por su lado, independientes entre sí, se sobreponen el día del espectáculo en un encuentro artístico abierto. Cunningham no quería darle la predominancia a ninguna de ellas. Si se quiere, proponía una Gestalt artística, donde el todo sumaba más que las partes.

Jacqueline Lesschaeve, amiga y gran conocedora de su trayectoria, entrevistó al coreógrafo en profundidad en su libro "El bailarín y la danza", texto al que se hace aquí referencia.

Decía pues Merce Cunningham:

En la mayoría de las coreografías convencionales existe una idea central a la que se adhiere todo lo demás: la coreografía se crea para una pieza musical, la música sirve de apoyo a la coreografía y el decorado lo enmarca todo. Cada una de las artes enfatiza la idea central. Lo que hemos hecho en nuestro trabajo es reunir en el espacio y el tiempo tres elementos separados -la música, la danza y el decorado- permitiendo que cada uno permaneciera independiente. Las tres artes no surgen de una única idea de que la danza muestra, la música apoya y el decorado ilustra sino que son tres elementos separados, cada uno central en sí mismo. (Lesschaeve, 2009, p. 165)

Con la integración de lo aleatorio en su obra, el coreógrafo quiso siempre sorprender al público y continuar su búsqueda de nuevos lenguajes. Gracias a la ayuda de expertos en informática, desarrolló el software "LIveform" que permitía crear y modelizar movimientos fortuitos, en unos tempos musicales también inesperados. Mediante la exploración de la escritura del movimiento apoyada por la informática, el camino hacia las nuevas tecnologías se empezaba a vislumbrar.

El tratamiento del tiempo es otra de las características que definen la identidad de Merce Cunningham. En sus coreografías, no se sigue el tempo de la música, compás a compás, sino el del cronómetro. Es la relación entre los movimientos de cada bailarín con los demás lo que determina la musicalidad. Esta no se impone desde afuera sino que, por más extraño que parezca, la lleva cada bailarín dentro de sí.

Por último, Cunningham modificó en sus coreografías la relación al espacio. Ya no es el de la perspectiva ni el de las diagonales. Cada bailarín es su propio centro, no hay un solista estrella. No hay, como en el ballet clásico, una prima ballerina y un cuerpo de baile que la acompaña en segundo plano, sino que cada uno es solista de su propio territorio. Encuentros y desencuentros en escena, el espacio se hace y se deshace, ante los ojos del espectador en su butaca quien decide, ante la multiplicidad de eventos en escena, sobre qué va a fijar la mirada. 
Un claro interés por las nuevas tecnologías, la exploración y destructuración del tiempo y del espacio, todo conducía pues a Cunningham a la creación de obras de video danza, aunque no se les diera ese apelativo en aquel entonces. Digamos simplemente que Merce Cunningham fue uno de los coreógrafos pioneros en apropiarse del video no como mero registro de la actividad artística y del movimiento, sino como un medio en sí.

Examinaremos ahora, a modo de ejemplo, una obra de Merce Cunningham, "Locale", que fue la segunda incursión del coreógrafo norteamericano en lo que Jacqueline Lesschaeve llama la "videocoreografía”.

La obra "Locale" fue creada originalmente en 1979 para video por Merce Cunningham y el realizador Charles Atlas; luego fue adaptada al teatro. Al ser concebida como coreografía para video, tuvieron que pensar en términos de cámara desde el principio. Primero, en términos operativos. Los dos artistas utilizaron cámaras fijas, y en soportes móviles como la Dolly, que desde su plataforma movible con ruedas suaviza los movimientos, así como la grúa telescópica, que facilita los travellings verticales $\mathrm{u}$ horizontales. Ambos dispositivos permiten desplazamientos controlados, que acompañan el movimiento.

Por otro lado, la escritura misma de la obra se pensó en función de la cámara, a partir de lo que se vería a través de ésta. Las dos versiones, dice el coreógrafo en la extensa conversación mantenida con Lesschaeve, son bastante diferentes entre sí, aunque en esencia sea la misma pieza. Sin embargo, hay una diferencia clara entre los dos productos, y no de menor talante: las cámaras seleccionan lo que ves mientras que en el escenario está todo ahí. Esta distinción es esencial cuando se habla de video danza: lo que percibe la audiencia del teatro es radicalmente diferente a lo que percibe el espectador en la pantalla. La mirada de éste se ve restringida por el encuadre de la cámara. En escena, se ve siempre a todo el mundo, nadie está fuera de plano. Al adaptar "Locale" para las tablas, Cunningham se vio confrontado a esta problemática. Tuvo que acomodar la obra que había creado para la pantalla de otra manera, para que sirviera los imperativos de una coreografía escénica.

Por otro lado, el coreógrafo quería mantener la sensación de rapidez, tan propia a la televisión, para la versión del teatro. Su determinación era mantener la idea de la multiplicidad de las imágenes simultáneas que se veían en la pantalla original. 
Algo que parecía moverse y luego de repente, detenerse. Evidentemente, el escenario modifica el espacio. Por ello, Cunningham incluyó desplazamientos y nuevas trayectorias en el teatro para facilitar las entradas y las salidas de los bailarines.

Una de las teorías principales de Merce Cunningham es que para él, el interés creativo residía en el camino que lleva de una figura a la otra. Lo que hace una coreografía es la transición de un movimiento hacia el otro, lo que le da el significado artístico global al momento dancístico es la "costura" que se hace entre dos pasos. Igual que al leer una partitura musical, se debe anticipar la lectura de la nota siguiente. Los ojos corren más rápido que la música. Afirmaba el coreógrafo:

Hace falta saber de dónde viene el movimiento, no en términos de expresividad sino de energía, de impulso, y hay que tenerlo claro para que se produzca el siguiente movimiento: si no empiezas a ver las cosas así, no consigues una progresión en los movimientos, una transición de uno a otro que parezca lógica. (Lesschaeve, 2009, p.78)

Esta postura de Cunningham es clave para entender el concepto de video danza. Pues al hablar de video danza, se hace justamente el camino inverso: se desenvuelve la madeja. Al editar la filmación, se rompe el desarrollo cronológico de la danza. Al hacer intervenir el montaje, se disuelve la progresión en los movimientos. La transición de una figura a la otra deja de ser la de la coreografía, aquella que parecía lógica en términos de Cunningham, para volverse (en apariencia) aleatoria. O por lo menos, para responder a las directivas de otro guión, que suplanta el de la coreografía original. ¿Y quién mejor que este maestro de la danza, quien había complejizado y analizado el movimiento y sus secuencias en su estado más puro, para convertirse en pionero de esta lógica en contravía? Pues en video danza se desestructura el movimiento original del bailarín. La coreografía inicial deja de tener el hilo conductor que el coreógrafo le impregnó al escribirla. No en términos de "historia" que pueda contar la obra, pues la danza contemporánea no posee una narrativa lineal como se puede identificar claramente en obras de ballet clásico tales como Giselle, La Bayadère o El lago de los Cisnes. No, más bien en términos de "empalme" entre los movimientos, o simplemente en términos de narrativa.

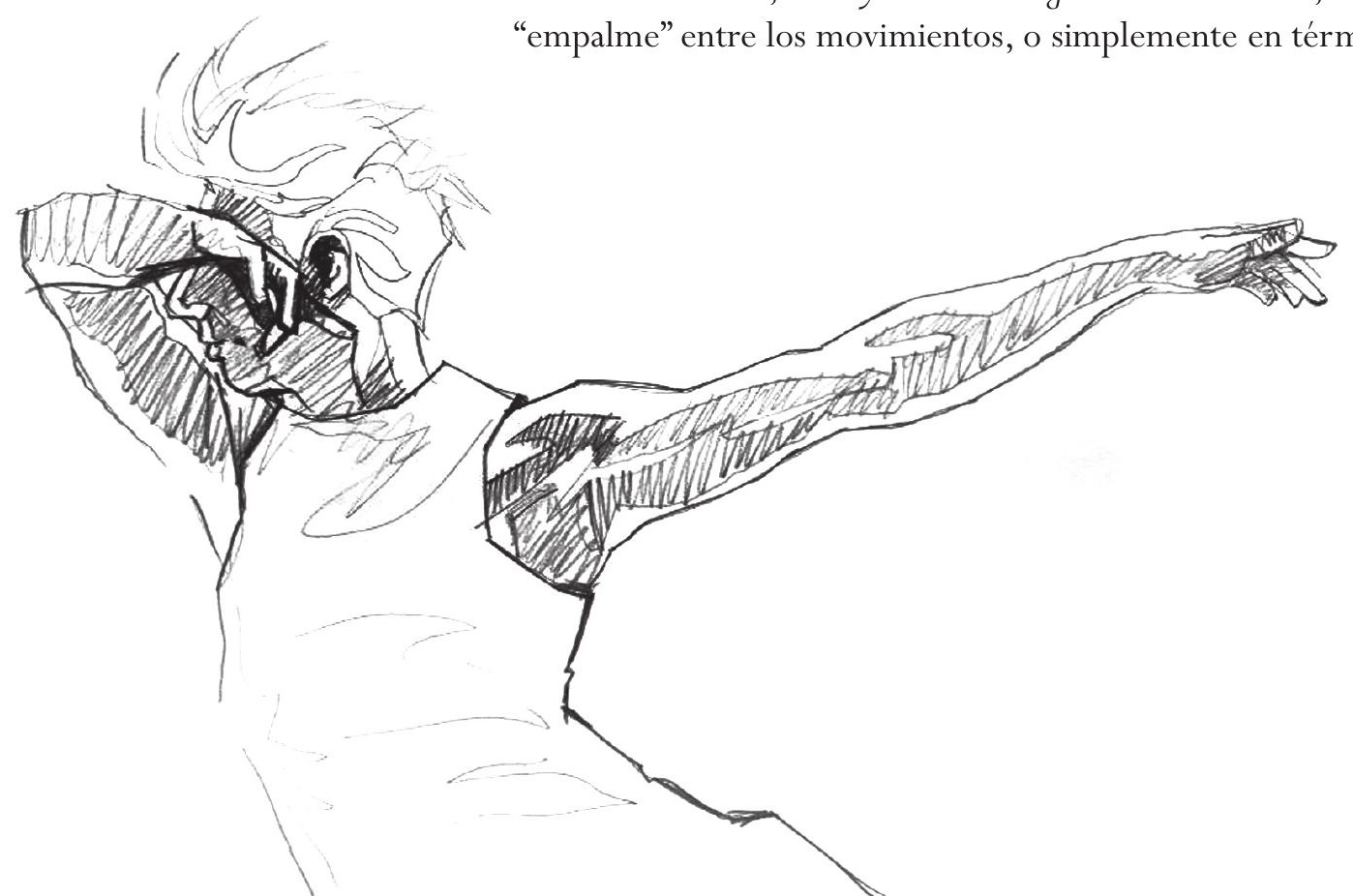


El texto que tensa esta argumentación, "El bailarín y la danza" de Jacqueline Lesschaeve, fue publicado por primera vez en 1980. Ya para entonces, Merce Cunningham vislumbraba las posibilidades del video como aliado de la danza.

Creo que la respuesta está en tener dos pantallas, una con el video de la coreografía y otra con una especie de apunte que la acompaña, que avanza en paralelo y es tridimensional: pueden ser figuras de palotes o lo que sea, pero se mueven en el espacio para que se puedan ver los detalles de la coreografía y detenerse en algo o pasarla a cámara lenta. (...) En una de las pantallas iría la nota que indicaría el lugar que ocupa cada persona, la forma del movimiento, el ritmo. En la otra pantalla, se vería qué aspecto tiene cuando lo ejecuta un bailarín. Cómo utilizar todo esto ya es otra historia, pero se podría detener la imagen y examinarla a fondo, pasarla a cámara lenta para observar los detalles, y no tendrían por qué verse simultáneamente siempre. (Lesschaeve, 2009, pp. 218-219)

Se había dado cuenta de la fuerte conexión que existe entre la danza y la televisión, por ser ambas visuales. Y proféticamente le aseguraba en 1980 a su amiga que las podría utilizar ambas, para el mayor beneficio de la danza:

Tengo la sensación de que el video evolucionará y se desarrollará mucho más que el cine: pronto las pantallas serán mucho más grandes y mejores y entonces la energía será muy diferente. Una vez bailamos en un gimnasio con pantallas que proyectaban imágenes de tamaño natural: hacíamos la coreografía tres veces, los bailarines empezaban después de las imágenes, en contrapunto más que sincronizadamente; la tercera vez sí se hacía sincronizado. Era como un juego, fue increíble. Yo lo había visto en una pantalla pequeña pero en las grandes toda la energía fluía de un modo muy distinto. (Lesschaeve, 2009, p. 224)

\section{La reproductibilidad de la obra de arte}

Ampliando el alcance de esta discusión, introduzcamos la postura de dos críticas francesas de danza, Isabelle Ginot y Marcelle Michel, quienes han estudiado la danza en el siglo XX en una extensa obra histórico-argumentativa ${ }^{10}$ :

Lo que preocupa particularmente a la danza es la cuestión de la visibilidad (y sobre todo, de la invisibilidad) del cuerpo y del movimiento. No su invisibilidad en tanto que imagen: el siglo XX, lo sabemos, habrá sido el de la exhibición y representación del cuerpo, en particular en formas comerciales. Más bien su invisibilidad en tanto que experiencia: en efecto, lo que resiste, lo que se pierde pide a ser nuevamente conquistado, es la experiencia del cuerpo cuando ha escapado del discurso o por lo menos, cuando no se deja limitar por él. 
La danza se esfuerza en volver visible o sensible algo de esta experiencia que ha venido a perturbar profundamente la distribución de las fuerzas y poderes en nuestras sociedades poderosamente logo centradas. La imagen, la representación, el discurso se esfuerzan por el contrario en tapar esta fuerza con el fin de disolver su poder. (Ginot \& Michel, 2002, p. 232)

Si retomamos lo aquí argumentado, podríamos decir que la danza (en vivo) retoma la experiencia del cuerpo cuando ha escapado del discurso o del poder o por lo menos, cuando no se deja delimitar por ellos. En ese orden de ideas, la imagen, la representación, el discurso, -o en otras palabras, el medio-, conscientes de ese potencial, se esforzarían por aniquilar esta fuerza con el fin de disolver su poder. Dicho de otro modo, la danza en vivo sería para estas francesas la expresión máxima de libertad pues haría el cuerpo visible, mientras que su expresión mediada, el video y el discurso, la condenarían a las estructuras de poder.

Siguiendo esta postura, el discurso mediado anihila el poder de la danza. La video danza, como expresión manipulada de la coreografía, se esfuerza en tapar el brillo de la obra original. O como diría Walter Benjamin, le hace perder el aura.

Los planteamientos de Ginot y Michel son muy discutibles e, in fine, los deWalter Benjamin.

Para darle peso a esta argumentación, nos detendremos ahora en la propuesta artística de un realizador cinematográfico que ya hemos citado, basándonos inicialmente en un texto suyo, Dancing for the camera, del año $2001^{11}$. Douglas Rosenberg, importante realizador norteamericano de video danza, es bien conocido por su alianza con grandes coreógrafos contemporáneos y su trabajo ha sido expuesto tanto en Estados Unidos como en otras partes del mundo en museos, galerías y festivales de danza. Esta complicidad con el mundo de la danza le ha hecho ser merecedor de importantes premios internacionales.

Douglas Rosenberg (2001) analiza el concepto de interpretación o actuación de una coreografía en vivo (performance), y lo describe como un tipo de reproducción corpórea donde se hace la transmisión de la coreografía en tiempo real. El trabajo de la danza, en este caso, es reproducido en el momento presente, en el aquí y el ahora; lo cual es completamente diferente a insertar un casete de video en un reproductor VHS para ver una obra de danza, o visionarla en una cinta en un video proyector o en un DVD en el sofá de su casa. Sin embargo, dice el teórico norteamericano, la cinta, al correr por el proyector, está reviviendo de alguna manera la pieza original. La vitalidad de la coreografía original se encuentra también en el medio a través del cual se reproduce. Cada actuación en vivo le devuelve la vida a la danza pero a la vez, el acto de visionar un video implica que se resucite el original. 
Vemos pues que para Rosenberg (2001) el tema de la reproductibilidad de la danza y de la obra de arte es clave. Desde ya se oponía a la teoría de Walter Benjamin, quien en su obra "La obra de arte en su época de su reproductibilidad técnica”, cuestionaba la autenticidad de la obra de arte técnicamente reproducida.

Escribía el filósofo alemán en 1936:

Incluso en la reproducción mejor acabada falta algo: el aquí y ahora de la obra de arte, su existencia irrepetible en el lugar en que se encuentra. También cuentan las alteraciones que haya padecido en su estructura física a lo largo del tiempo, así como sus eventuales cambios de propietario (...). Las circunstancias en que se ponga al producto de la reproducción de una obra de arte, quizás dejen intacta la consistencia de ésta, pero en cualquier caso deprecian su aquí y ahora. (Benjamin, 1979, pp. 2-3)
La obra de arte, al ser técnicamente reproducida, es una obra de arte depreciada, en términos de Benjamin, por lo menos en su existencia actual. En la época de la reproducción técnica de la obra de arte lo que se atrofia es su aura, o aquella "manifestación irrepetible de una lejanía (por cercana que pueda estar)". Al ser reproducida, se pierde la unicidad de la obra de arte, lo que la hace única. O en otras palabras estamos hablando de eso que Benjamin llama la liquidación completa de la autenticidad. "La técnica reproductiva desvincula lo reproducido del ámbito de la tradición. Al multiplicar las reproducciones pone su presencia masiva en el lugar de una presencia irrepetible" (Benjamin, 1979, p. 3).

Dos investigadores uruguayos, Diego Carrera y Magali Pastorino supieron interpretar el pensamiento de Walter Benjamin cuando éste hace referencia al carácter aurático de la obra:

Se refiere a la reflexión del filósofo sobre cómo la técnica que reproduce puede aproximar los objetos artísticos a un público de masas. La diferencia que había entre el original y la copia se desvanece. Lo que antes pertenecía a una élite, hoy puede ser accesible. Pero el punto aquí, es que la técnica ya no es algo suplementario o accidental de la obra, sino su esencia. La técnica, entonces interesa cuando tiene la capacidad de abrir nuevas posibilidades estéticas y nuevas relaciones con el espectador. Depara una transformación en el campo de producción de subjetividad social, y de este modo, el receptor cobra nuevo protagonismo, no ya como un contemplador en el esquema clásico, sino como un espectador activo. ${ }^{12}$ 
Frente a esta postura, Douglas Rosenberg se rebela. La video danza nunca podrá ser la danza en sí, mucho menos la coreografía original. Investigador, realizador, productor de video danza, Rosenberg la defiende y sostiene que para que ésta práctica artística exista, el original (la coreografía) es sacrificada para que pueda nacer una nueva especie, enriquecida de otros medios.

Aceptar el planteamiento de Benjamin significa para Rosenberg una claudicación que no está dispuesto a consentir. Sería negar el poder que tienen las obras de video danza mecánicamente o virtualmente reproducidas como "Locale" de Merce Cunningham, o como tantos otros artistas que han desafiado exitosamente las afirmaciones de Benjamin y que han logrado reinstaurar el aura de la coreografía en el mundo de la video danza.

Esta negación del pensamiento de Benjamin se recoge en la siguiente cita de Douglas Rosenberg:

La línea entre la danza para el teatro y la danza para la cámara se ha tornado cada vez más borrosa en esta era de la reproducción digital. El medio digital ha creado una cultura no lineal y descentralizada que cuestiona el valor del original. En otras palabras, una copia de información digitalmente reproducida tiene tanto valor como cualquier otra copia. Como la danza vive en el cuerpo, tanto en el del bailarín como en el del espectador, se resiste a su reproducción digital. Sin embargo, los artistas que trabajan con imágenes en movimiento, persisten, generalmente con éxito, en su búsqueda por sobrepasar los problemas asociados a la reproducción de la experiencia corpórea de la danza ${ }^{13}$. (Douglas, 2001)

Se puede disentir de ambas posturas. Razón tiene Benjamin al afirmar que la obra de arte reproducida ha perdido su autenticidad. La danza ha sido manipulada, objetivada, desestructurada, en efecto. Bien lo decía el propio Rosenberg, la coreografía original ha sido sacrificada en pos de una nueva "criatura". No es la misma danza, no es el mismo cuerpo. Ha perdido su aquí y su ahora.

Sin embargo, esta reproducción técnica de la danza que se logra gracias al video no significa de ninguna manera que el resultado sea desdeñable. No es, como dice Benjamin, una obra de arte depreciada. Es sencillamente otra obra de arte. La reproducción técnica que propone la video danza, con la utilización del lenguaje y códigos propios del cine, no destruye la danza. Por el contrario, como ha sido visto en este texto, la enriquece, solo que se manifiesta a través de otro producto. El no comprender esta posición es lo que quizás haya generado el desconocimiento al que se hacía referencia en la introducción de este texto, si no el desdén, hacia la video danza. 


\section{Douglas Rosenberg o el cuerpo invisible}

Para finalizar con este contrapeso teórico, y ya situándonos del lado del video, seguiremos analizando el medio utilizado en video danza en cuanto productor de significados y significantes.

La proxémica, tal y como la define el antropólogo y comunicador Alejandro Grimson en su libro "Interculturalidad y Comunicación", refiere al uso y significado del espacio físico por el ser humano, su organización o disposición. Es el estudio de la percepción del espacio, de su intimidad personal; de cómo y con quién lo utiliza. Generalmente da cuenta de expresiones de intimidad y poder.

"El contacto entre personas y grupos que perciben como naturales usos y significados diferentes del espacio, el cuerpo, la palabra, el tacto y otros elementos de la Comunicación, se produce tanto en situaciones de co-presencia física, como en marcos de distancia espacio-temporal”.

(Grimson, 2001, p. 96)

Podríamos asimilar los marcos de distancia espacio-temporal a los que Alejandro Grimson hace referencia como el medio empleado para la difusión de la video danza, la pantalla que aleja pero a su vez, acerca al espectador.

Para Rosenberg, el cuerpo es un complejo sistema de símbolos, signos y códigos. El ojo del espectador cobija, de una sola mirada, una explosión de información. Todo en el cuerpo comunica y todo el cuerpo comunica. Cuando el cuerpo que baila es ubicado en un contexto de registro cinematográfico, o en otras palabras, contextualizado por su forma de representación, otras capas de significados y metáforas vienen a añadirse y conspiran en la creación de una narrativa adicional. Al cuerpo que baila se le añaden otras informaciones, textuales, visuales, sonoras, de iluminaciones, provenientes de otros intérpretes, y se le añade además una audiencia que es determinada por el medio. Esa audiencia que mira a través del lente de la cámara o a través de la pantalla de su televisor, tiene una experiencia sensorial completamente diferente a aquella que se encuentra percibiendo la danza en vivo. Es, para nosotros, otro espectador: es un espectador mediado. Este se nutre de toda aquella información adicional. La polisemia es mayor gracias a la intervención del medio. Como dice Valeria Cotaimich:

Ya no se puede hablar de un mensaje homogéneo controlado por un sujeto creador que garantiza la coherencia estética, sino más bien de una transformación de la práctica escénica en un montaje, en una práctica significante, que promueve un 'encuentro', un diálogo entre distintas subjetividades, distintos soportes y distintos modos de percibir, concebir y construir el mundo (...). Este diálogo puede ser considerado en términos de intermedialidad e intertextualidad. ${ }^{14}$

(Cotaimich, 2004, p.5) 
$\mathrm{Al}$ hacer referencia a la resurrección del original a través de la copia, dice Rosenberg que ésa es una actuación interactiva que requiere del espectador su participación en tanto que "receptáculo" de la información difundida. La implicación del espectador de video danza es tal que debe, por encima de todo, dejar de lado sus expectativas y prejuicios históricamente concebidos en torno a la danza. La danza en la pantalla puede resultar muy extraña para la propia danza -y para los espectadores podría añadirse. Para poder apreciar la video danza, se debe partir del siguiente concepto: lo que se va a ver NO ES DANZA. El espectador tiene una experiencia habitual al asistir al teatro, que se funda en sus vivencias anteriores en estos espacios. Esa referencia, construida con base a su relación espacio/temporal con el lugar, se rompe con la video danza.

Para empezar, la música no es la de la danza, es la del video. Los bailarines no acompañan la música escrita para la coreografía, (lo veíamos con la propuesta de Merce Cunningham), son las imágenes y los planos quienes bailan al son de la música de fondo. Se añade la música en la postproducción.

Luego, grabar una coreografía no significa que se capte la esencia de la obra. Para ello, no se trata solamente de poner una cámara que siga los movimientos del bailarín. Hay que lograr darle vida a la cámara, crear movimientos, efectos, campos dentro de la imagen, a través de la alteración de la velocidad, los ralentíes, la integración de sonidos, los close up al movimiento. Hacer video danza no se trata de hacer un "ballet filmado", como dice el realizador de video arte Robert Cahen.

No se puede pretender grabar toda la escena o todo el cuerpo del bailarín. Tampoco tiene interés. Basta con filmar unos dedos que se muevan o un torso que se dobla para tener la ilusión de todo un cuerpo en movimiento. Si los pies o las manos desaparecen del cuadro, no importa. En la video danza, no se trata de reproducir el movimiento entero. Imaginar más que ver.
Que sea Stéphane Mallarmé, gran escritor francés del siglo XIX, quien lo exprese mejor. Escribía el poeta en 1897:

Hay que entender que la bailarina no es una mujer que baila por estas dos razones yuxtapuestas. Porque no es una mujer sino una metáfora que sintetiza uno de los aspectos fundamentales de nuestra forma, una espada, una copa, una flor, etc.; y que no baila, gracias al prodigio de atajos o de impulsos, con una escritura corporal, lo que necesitaría párrafos enteros en prosa dialogada como descriptiva, para expresar, en la redacción, un poema que se desprende de todo el aparataje del escriba. (Mallarmé, 1897, p. 173) ${ }^{15}$.

Metáfora y poesía, reconstrucción encarnada en el medio, la danza para la pantalla no es danza. Cuando el cuerpo que baila se inscribe en el campo de la tecnología, el complejo sistema de producción de significados se complejiza aún más gracias a lo que Rosenberg llama "la recorporeización del cuerpo que baila”. Este es un concepto esencial en el pensamiento de Rosenberg y evidentemente, clave para la edificación de este artículo.

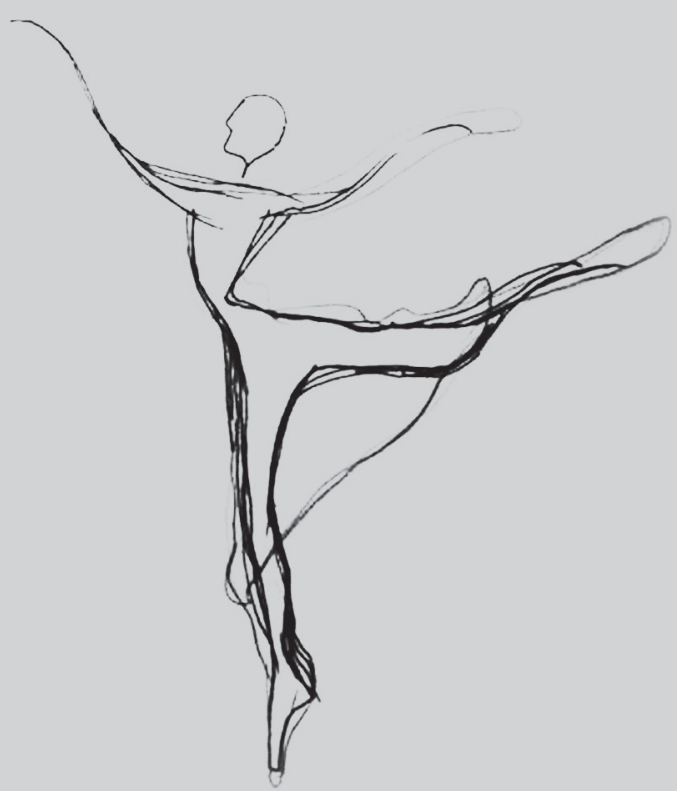


"La recorporeización del cuerpo que baila” consiste pues en darle nuevamente una forma a ese cuerpo que baila para la cámara, que fue desmembrado por la intromisión de la tecnología, a ese cuerpo que ha surgido de la intervención del montaje y la inclusión de toda clase de efectos. El cuerpo que baila en el teatro es uno y se presenta en tiempo presente, tal cual es. El cuerpo que baila para la cámara es otro, ya no en su presente sino en tiempo pasado, casi que congelado en el tiempo.Y definitivamente, el cuerpo que baila en la pantalla es un tercer cuerpo. Tres tiempos - presente, pasado y futuro- que podrían ser también los tres momentos de la coreografía: la coreografía del movimiento, la coreografía de la cámara y por último, la coreografía de la edición. Tiempo presente-coreografía del movimiento; tiempo pasado-coreografía de la cámara; tiempo futuro-coreografía de la edición.

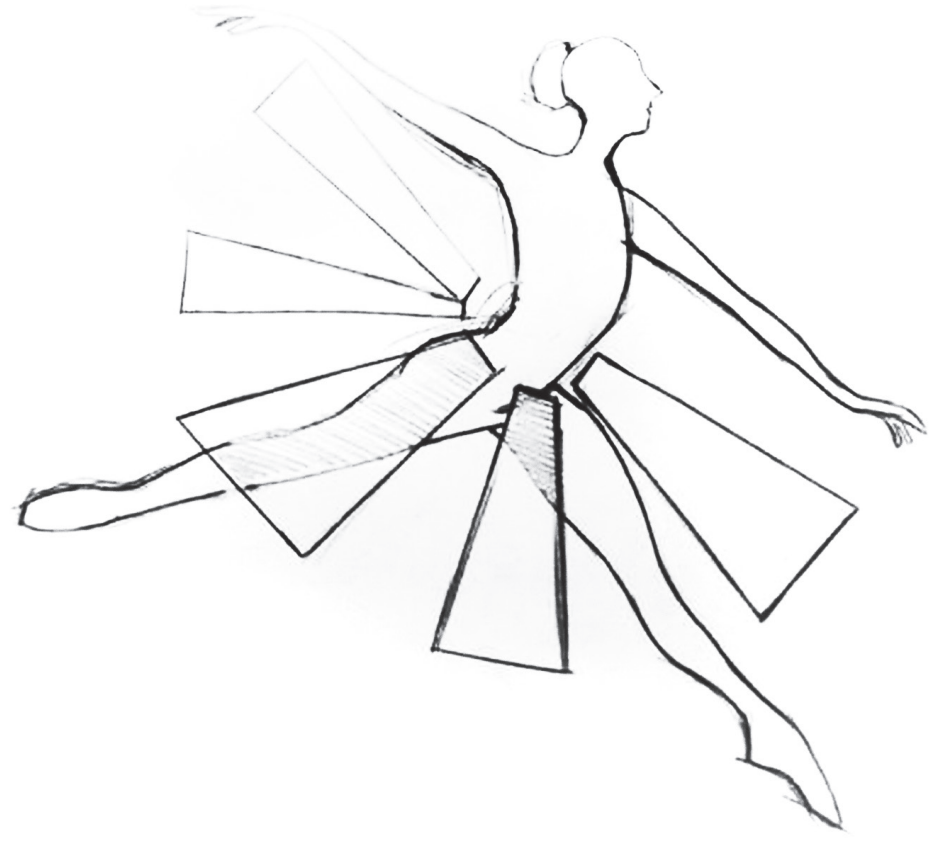

En video danza, el cuerpo que vemos es también un cuerpo mediado. Es un cuerpo encuadrado, iluminado, editado, sonorizado, enmendado (¿remendado?). Es un cuerpo (re)construido, concluye Rosenberg, un cuerpo que puede o no existir y que desafía las leyes de la gravedad, del peso, de la naturaleza, el espacio y el tiempo. La video danza es el encuentro del cuerpo encarnado (el cuerpo del bailarín) con el cuerpo desmaterializado del video. Rodrigo Alonso lo expresa claramente: "Qué otra cosa podría ser la video danza sino un encuentro casual, producto del vínculo entre uno de los medios de expresión más antiguos del hombre y uno de los más contemporáneos, insospechado resultado de la puesta en común de un medio encarnado en la materialidad del cuerpo con un medio descorporeizado, abstracto, casi inhumano?". ${ }^{16}$

En otro artículo ${ }^{17}$, también del 2001, donde Rosenberg evoca la (de)construcción de la danza para el ciberespacio, -otras pantallas y otras tecnologías pero cuyos usos se podrían equiparar a los del video-, el videoartista llega a una afirmación provocadora y brutal: en la web, el cuerpo se vuelve obsoleto. El discurso utilizado para describir las interpretaciones que utilizan procedimientos multimediáticos es neutro al referirse al cuerpo, como si éste no tuviera códigos, etnicidad u otras marcas. La pantalla minimiza las diferencias, lima los surcos de la edad, hace desaparecer los rasgos étnicos y de género. La utilización de las tecnologías desplaza al bailarín por el uso de la imagen y los artificios de creación. El cuerpo mediado es invisible.

Pero esta invisibilidad corporal es múltiple. La danza es la adoración del cuerpo, arguye Rosenberg, el cuerpo se vuelve centro de atención, el cuerpo es ego, es punto focal. Cuando se utiliza el video como simple registro de la danza, pareciera como si la tecnología se quisiera abstraer de ese ego: entre menos se sienta, mejor. Que no haya desenfoques, cortes abruptos o ¡Dios nos libre!, manos temblorosas al hacer un zoom. 
Que no se sienta la presencia de la cámara. Se pretende conscientemente borrar las marcas de la producción. El video debe mostrar de la manera más fiel posible, el cuerpo y sus movimientos para asegurar la reproductibilidad fidedigna de la coreografía. La cámara es invisible. El autor del video no existe. El cuerpo no se deja mediar.

Se operan pues procesos de producción de sentido en el espectador al tener la visión de un cuerpo en movimiento a través de la cámara, transformándole la mirada y convocando a la experiencia del tiempo expandido, es decir, del tiempo del acontecimiento inscrito en la imagen técnica.

Como dice Valeria Cotaimich ${ }^{18}$ :

El espectador toca con los ojos en lugar de tocar con las manos, modela su esquema corporal a partir del esquema corporal del actor, el espectador aprende de nuevo a ver y pone en duda el modelo de corporeidad sostenido en una visión clásica panóptica y fragmentada, lo que deriva en un movimiento continuo de la visión.

La práctica artística de la video danza ha transformado la producción de miradas. Gracias a los manejos del tiempo y el espacio, más que la danza de los cuerpos, se crea una verdadera danza de las imágenes. Pareciera pues como si el objeto de la video danza fuera crear, más que cuerpos en movimiento, terreno por excelencia de la coreografía, imágenes en movimiento donde el espectador mediado tiene un rol esencial.

Pero en la video danza, el cuerpo sigue siendo el centro del registro. Un cuerpo que se dobla y se desdobla para la pantalla. Volvamos a evocar pues, ya para terminar, a Rodrigo Alonso, de quien ha sido tomada en préstamo su bella alegoría: la video danza es la coreografía de la mirada.

$\mathrm{Y}$ es que el cuerpo, ese instrumento que es el presupuesto de la composición coreográfica, no ha dejado de ser el protagonista. Un cuerpo que la mediación transforma en superficie pero que paradójicamente parece más inmediato, merced a los acercamientos de la cámara. Un cuerpo que exige ser tratado de otra forma, porque el coreógrafo ya no debe diseñar sólo su movimiento: también debe diseñar la mirada que lo recorrerá. Esta coreografía de la mirada es tal vez lo que mejor define a la video danza, lo que le da su fuerza estética y lo que justifica su razón de ser dentro del arte contemporáneo ${ }^{19}$.

El navío se ha estrellado contra los arrecifes. Las criaturas marinas hicieron su trabajo, la video danza ha echado su hechizo. Pero el viaje valió la pena. "Hay que aprender no solo a usar el video sino también a mirar las imágenes que produce” solía decir Merce Cunningham. De la misma manera, hay que aprender no solo a mirar la danza sino también a mirar las imágenes que produce. Aprender a desestructurar para volver a construir. 
Definitivamente, el viaje valió la pena. Los monstruos que habitan la chica del pelo corto la dejarán dormir esta noche.

\section{Notas}

${ }^{1}$ Rosenberg, Douglas: http: / /www.videodanza.com/

${ }^{2}$ Alonso, Rodrigo, "Video Danza, otro bastardo en la familia”: http: / / www.roalonso.net/es/ videoarte/bastardo.php

${ }^{3}$ Rosenberg, Douglas: op. Cit

${ }^{4}$ Carvalho, Cassio, "Contrapeso": http: / /www.youtube.com/watch?v =mUHm9S4XXz8

${ }^{5}$ Carrillo, Rebeca, "La video danza, la escondida incógnita”: http: / / publicaciones.zemos98.org/ la-video-danza-la-escondida

${ }^{6}$ García, Elena, "Danza y tecnología II”: http://www.luciernaga-clap.com.ar/articulosrevistas/9_ danza.htm

${ }^{7}$ Alonso, Rodrigo, op. Cit.

${ }^{8}$ Rosenberg, Douglas, "Video Space: a site for technology": http://www.dvpg.net/essays.html. Esta es una referencia encontrada en Internet, sin paginación ni datos de publicación. El texto original está en inglés. Las traducciones son todas mías.

${ }^{9}$ Cotaimich, Valeria, "El impacto de las nuevas tecnologías en la puesta en escena. La estética dialógica como desafío estético, poético y político”. Proyecto que forma parte de una indagación a cargo del 'Programa de Antropología Poética' del Centro de Investigaciones de la Facultad de Filosofía y Humanidades de la Universidad Nacional de Córdoba, Argentina. No hay referencias de publicación ni paginación de esta investigación.

${ }^{10}$ Ginot, Isabelle ; Michel, Marcelle (2002), La danse au XXè siecle. El texto original está en francés. Las traducciones son mías.

${ }^{11}$ Rosenberg, Douglas, 2001 (1): “Dancing for the camera”: http://www.dvpg.net/essays.html. Esta es una referencia encontrada en Internet, sin paginación ni datos de publicación. El texto original está en inglés. Las traducciones son todas mías.

${ }^{12}$ Carrera, Diego \& Pastorino, Magali : "Video danza, Máquina y cuerpo”, FIVU 2005: http: / / www.videodanza.com/textos/maquina\%20y\%20cuerpo.htm

${ }^{13}$ Rosenberg, Douglas, op. Cit 2001 (1)

${ }^{14}$ Cotaimich, Valeria, op. Cit

${ }^{15}$ Mallarmé, Stéphane (1897). Divagations. El texto original está en francés. Las traducciones son todas mías.

${ }^{16}$ Alonso, Rodrigo, op. Cit.

${ }^{17}$ Rosenberg, Douglas, 2001 (2): "Notes on the intersection of Dance and Technology": http: / / www.dvpg.net/essays.html Esta es una referencia encontrada en Internet, sin paginación ni datos de publicación: El texto original está en inglés. Las traducciones son todas mías.

${ }^{18}$ Cotaimich, Valeria, op. Cit

${ }^{19}$ Alonso, Rodrigo, op. Cit. 


\section{Referencias}

Alonso, R., Video Danza, otro bastardo en la familia. http: / / www.roalonso.net/es/videoarte/bastardo.php

Benjamin, W. (1989). La obra de arte en la época de su reproductibilidad técnica. En Discursos Interrumpidos I. Buenos Aires: Taurus.

Carrera, D. \& Pastorino, M. Video danza, Máquina y cuerpo, FIVU 2005: http: / /www. videodanza.com/textos/maquina\%20y\%20cuerpo.htm

Carrillo, R. La video danza, la escondida incógnita. http: / / publicaciones.zemos98.org/la-video-danza-la-escondida

Carvalho, C. Contrapeso. http: / / www.youtube.com/watch?v=mUHm9S4XXz8

Cotaimich, V., El impacto de las nuevas tecnologías en la puesta en escena. La estética dialógica como desafío estético, poético y político. Centro de Investigaciones, Facultad de Filosofía y Humanidades, Universidad Nacional de Córdoba, Argentina.

Dança en foco (2012). Ensaois contemporaneaos de videodança. Rio de Janeiro: Aeroplano Editora e Consultoria Ltda.

García, E., Danza y tecnología II: http://www.luciernaga-clap.com.ar/articulosrevistas/9_danza.htm

Ginot, I. \& Michel, M. (2002). La danse au XXè siecle. Paris: Editions. Larousse/Vuef.

Grimson, A. (2001). Interculturalidad y Comunicación. Bogotá: Grupo editorial Norma.

Olivares, V., \& Isse, M. M. (2011). Danza: Investigación en Argentina. Buenos Aires: Balletin Dance Ediciones. Lesschaeve, J. (2009). El bailarín y la danza. Conversaciones con Merce Cunningham. Barcelona: Global Rythm Press.

Mallarmé, S. (1897). Divagations. Paris: Eugène Fasqueue Editeur.

Noisette, P. (2011). Talk about contemporary dance. Paris: Flammarion.

Rosenberg, D. "Video Space: a site for technology": http://www.dvpg.net/essays.html.

"Dancing for the camera", 2001 (1): http://www.dvpg.net/essays.html.

"Notes on the intersection of Dance and Technology", 2001 (2):

http://www.dvpg.net/ essays.html.

Recibido: abril 15 / Aprobado: junio 1 de 2014 


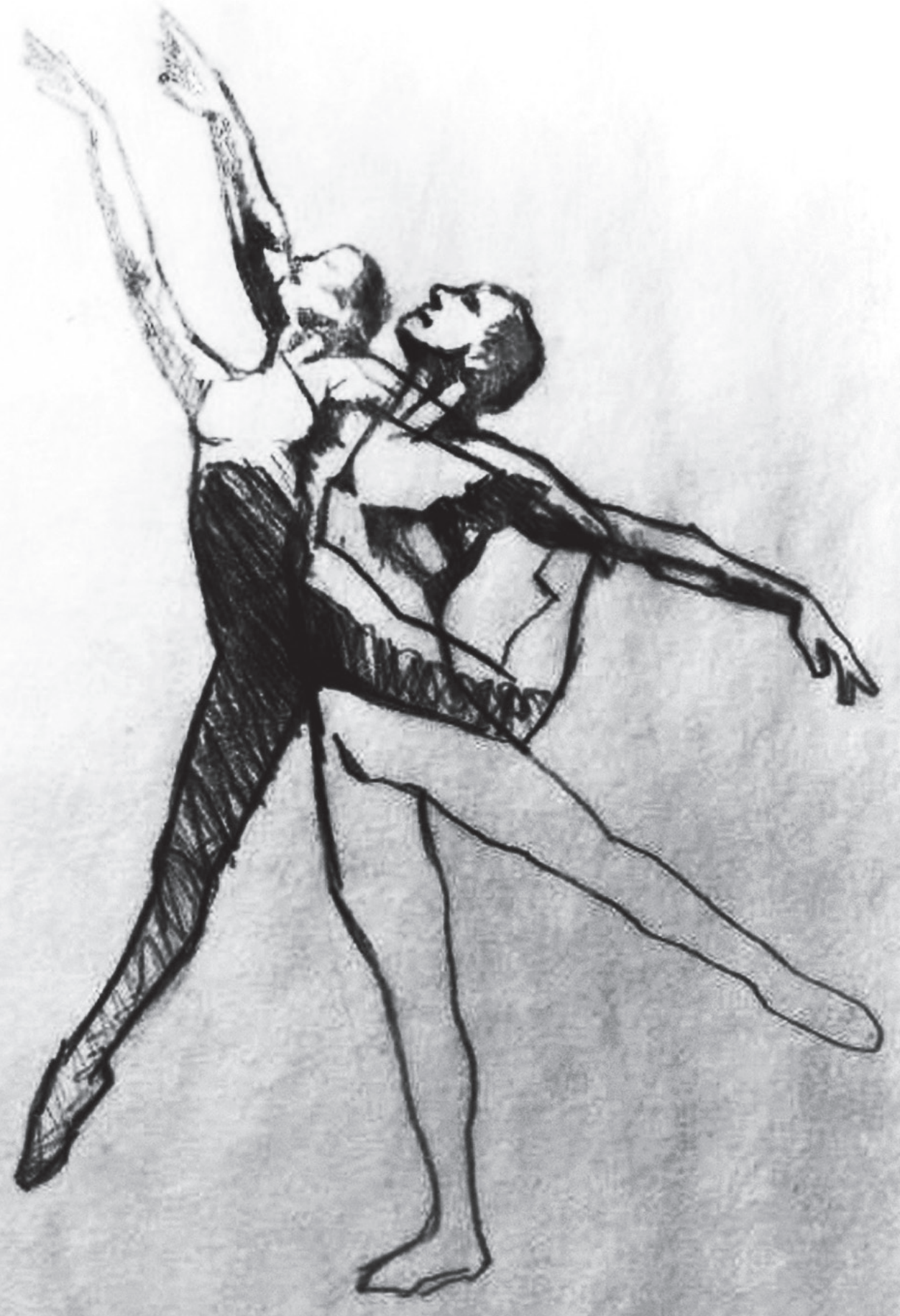

